
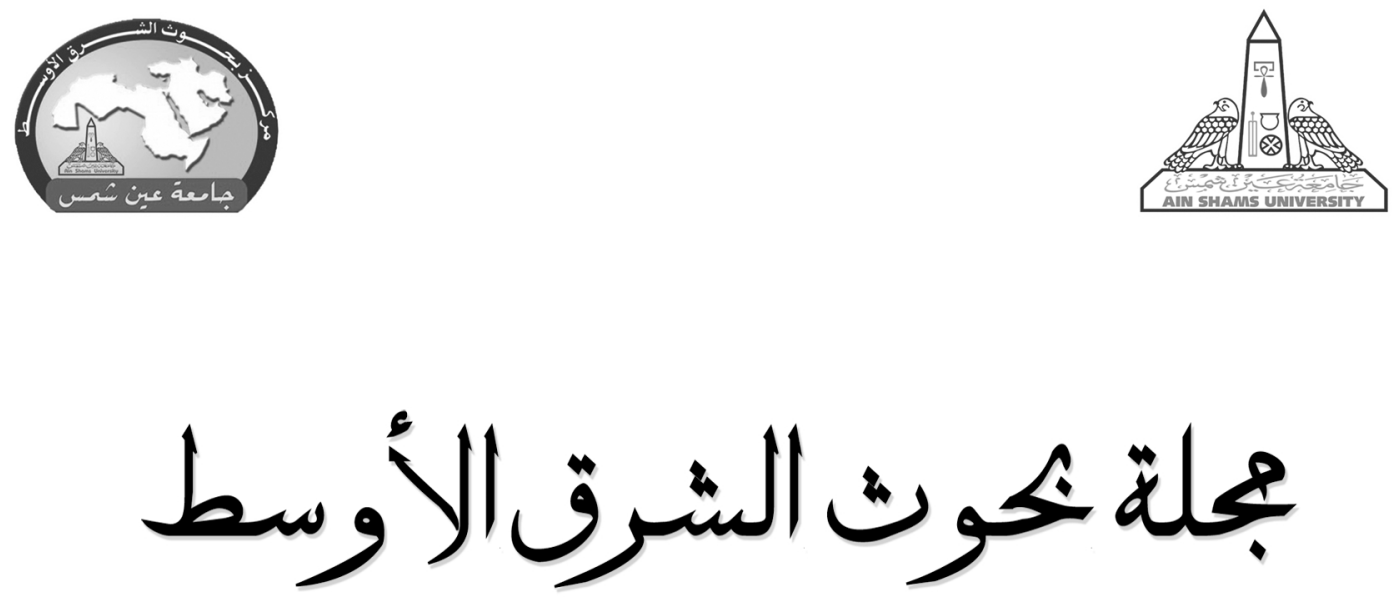

مجلة عامية مصكمة ( مهتمدةة ) شهرية

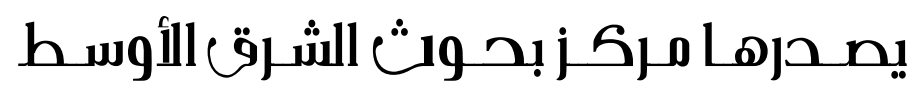

السنة الثامنة والأوبمون - تأسست عام $19 v 8$

العدد الواحد والسبعون ( يناير rץ • r)

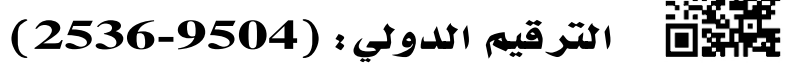

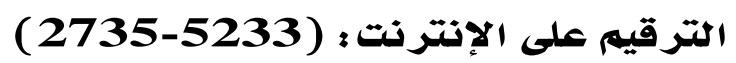




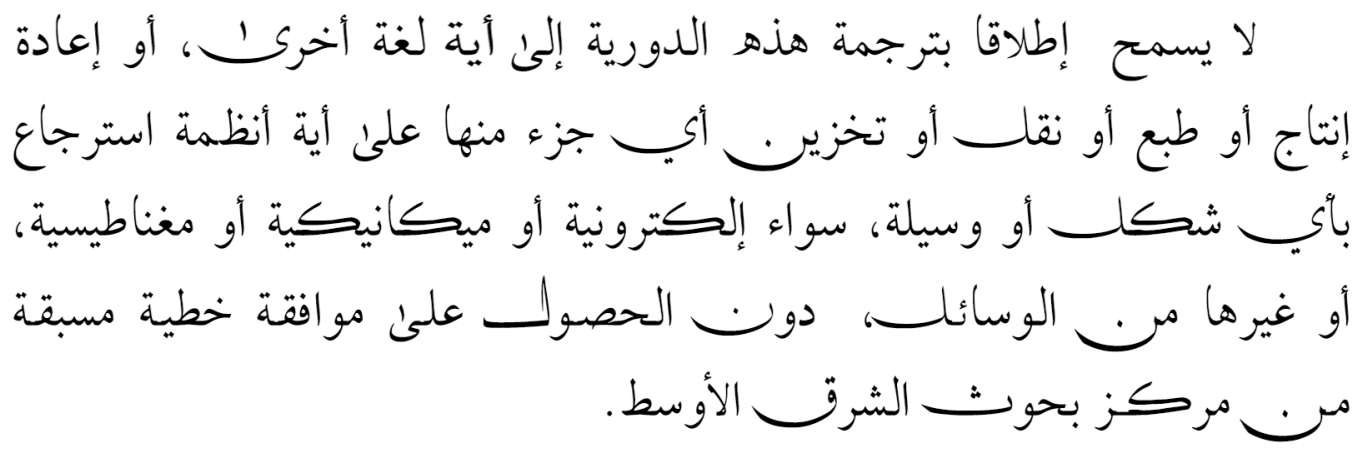

All rights reserved. This Periodical is protected by copyright. No part of it may be reproduced, stored in a retrieval system, or transmitted in any form or by any means, electronic, mechanical, photocopying, recording, or otherwise, without written permission from The Middle East Research Center.

الأراء الواردة داخل المجلة تعبر عن وجهة نظر أصحابها وليست مسئولية مركز بحوث الشرق الأوسط والدراسات المستقبلية

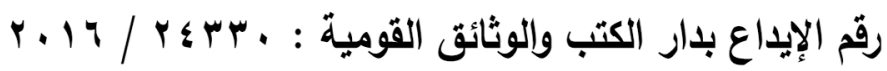

الترقيم الدولي: (Issn : 2536 - (Is04)

التر قيه على الإنترنت: (O233 - 2735) : 


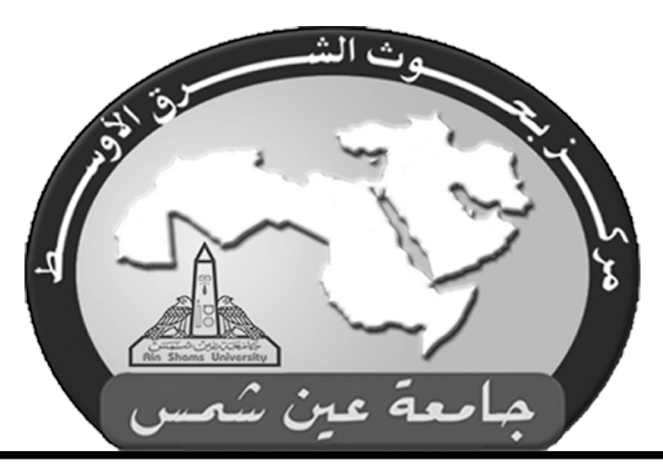

\section{مجلة بحوث الشرق الأوسط}

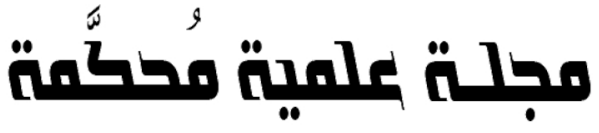

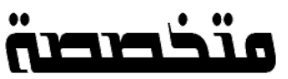

\section{في تسئون التقرق الأوسط}

\section{مجلة مُعتمَدة من بنك المعرفة المصري}

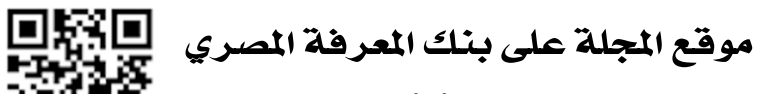

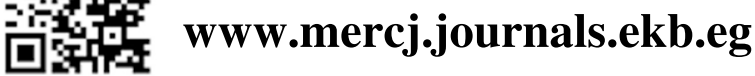

- معتمدة من الكثاف العربي للاستشهادات المرجعية (ARCI) ـ المتوافقة مع قاعدة بيانات

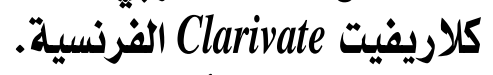

- معتمدة من مؤسسة أرسيف (ARCIf) للاستشهادات المرجعية للمجلات العلمية العربية

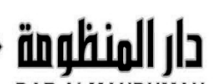

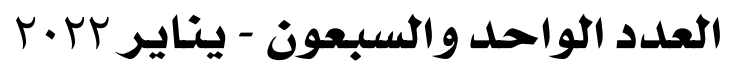

تصدر شهريًّا

السبنة الثامنحة والأربعوث - تأسست عام

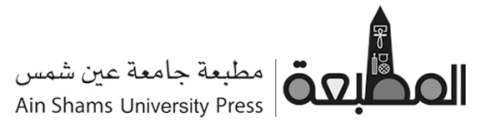




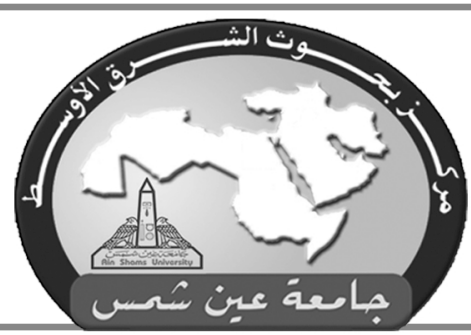

مجلة بحوث الشرث الأوسط (مجلة مُعتمدة)

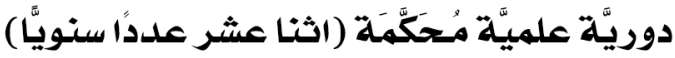

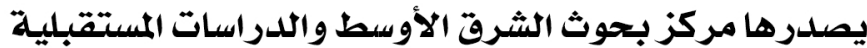

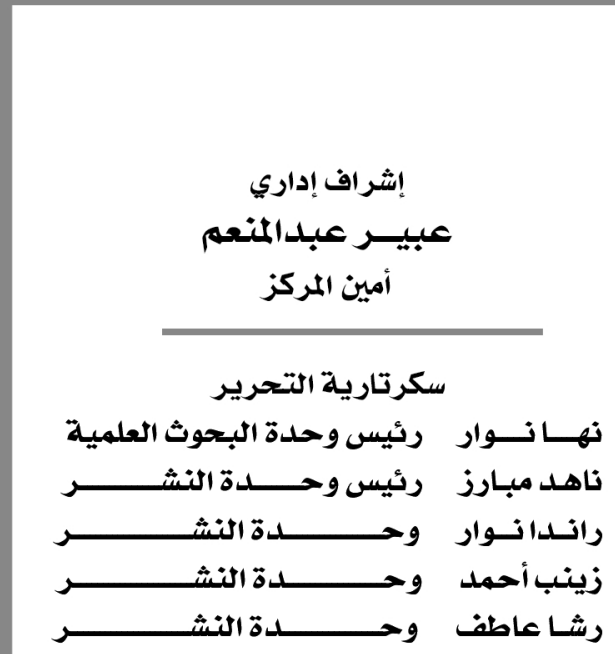

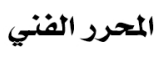

ياسر عبد العزيز رئيس وحدة الدئ الدعم الفني

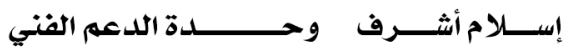
تنفيذ الغلاف والتجهيز والإخراج الفني وحدة الدعم الفني

تدقيق ومراجعة لغوية

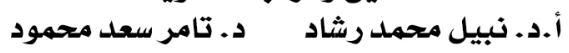
تصميه الغلاف أ.د. وائل القاضي دئي
رئيس مجلس الإدارة

الأستاذ الدكتور / هشام تقراز

نائب رئيس الجامعة لشئون المجتهع وتنهية البيئة

ورئيس مجلس إدارة المركز

رئيس التحرير

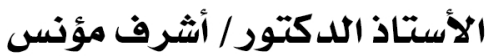
مدير مركز بحوث الشرق الأوسط الأسئ والدراسات المستقبلية

هيئة التحرير

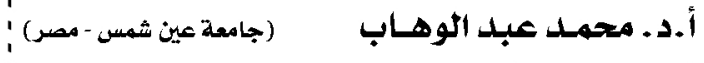

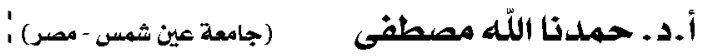

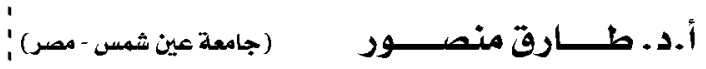

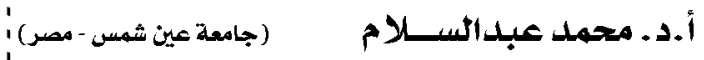
أ.د. وجييه عبد الصادق عتيق (جامعة القاهرة - مصر)':

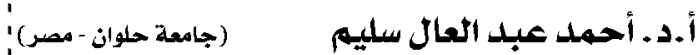

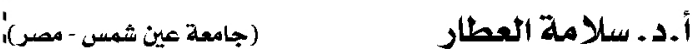

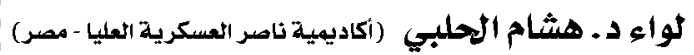

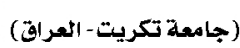
أ.د. محمدل يوسف القر يشي

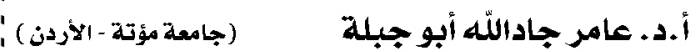
أ.د. ثبيلة عبد الشكور حساني (جامعة الجزاثرب - الجزائر) '

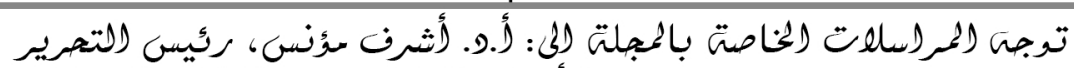

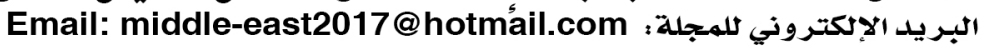

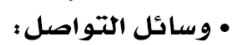

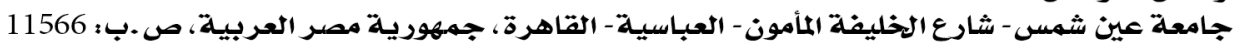

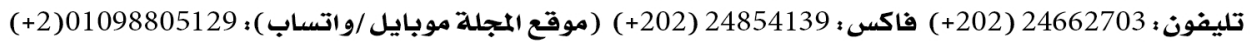

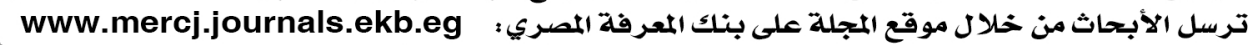
ولن يلتفت إلى الأبحاث المعرسلة عن طرئل طريق آخر 


\section{همحلت بحوث الشرق الأوسط}

- رئيس التحرير أ.د. أشرف مؤنس

- الهيئة الاستشارية المصرية وفقًا للترتيب الهجائي؛

• أ. د. إبراهيه عبد المنعم سلامة أبو العلا رئيس قسم التّاريخ - كلية الآداب - جامعة الأنكندرية - مصر

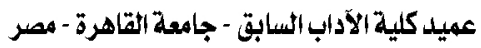

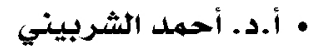

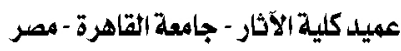

عميد معهد البحوث والدر اسات الأفريقية السابق - جاهعة القاهرة - هصر

رئيس قسيه التاريخ السابق - كلية الآداب - جامعة القاهرة - مصر

رئيس الجهعية المصرية للدراسات التاريخية - هصر

كلية الدراسات العليا للطثولة - جامعلة عين شهس - مصر

كلية المقوق - جاهعة عين شهس - هصر

وكيل كلية الاداب لشئون التعليم والطلاب - جامعة عين شهس - مصر

رئيس قسيم التاريخ والمضارة الأسبق - كلية اللغة العربية

فرعاززقازيق - جاهعة الأزهر - مصر

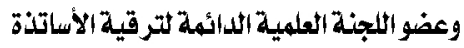

كلية الآداب - جاعدةالمنيا،

ومقرر لجنة التر قيات بالمجلس الأعلى للجامعات - عصر

عميل كلية الآداب الأسبق - جامعلة حلوان - مصر

كلية اللفة العربية بالمنصورة - جامعة الأزهر - مصر

كلية اللدراسات الإنسانية بنات بالقاهرة - جامعة الأزهر - هصر

كلية الآداب - جامعة بنها - مصر

كلية الآداب - نائب رئيس جامعة عين شمس السبابق - هصر عهيد كلية العلوم الاجتهاعية والإنسانية - جامعة الجلالة - مصر

كلية التزبية - جامعة عين شهس - هصر

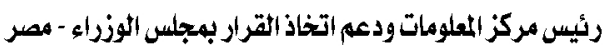

كلية الآداب - جامعة عين شمس - مصر

كلية الخدمة|لاجتماعية - جامعة حلوان

قطاع الخذهة الاجتهاعية بالمجلس الأعلى للجامعات ورئيس لاجنة ترقية الأساتذة

كلية التربية - جامعة عين شهس - مصر

كلية الآداب - جاعقة المنيا - هصر

كلية السياحة والفنادة - جامعة مليندا السادات - مصر - مهر

• أ.د. عادل عبد الحافظ عثهان حهزة

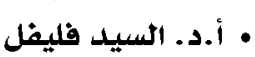

• أ.د. إيهان محهد عبد المنحم عامر أدمر

• أ.د. أيهن فؤاد سيد أدهان

• أ.د. جهال شفيق أحهد محهد عاهر

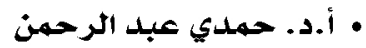

• أ.د. حنان كامل متولي

• أ.د. صاثح حسن الخسلوث

.

• أ.د. عاصم الدسوقي

• أ.د. عبد الحهيد شلبي

• أ.د. عفاف سيد صبره

• أ.د. عثيفي محهود إبراهيه عبدالله أديله • أ.د. فتحي الشرقاوي

• أ.د. محهد الخزامي محهد عزيز أدهيز

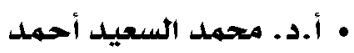

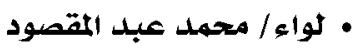

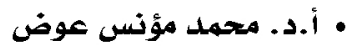

• أ.د. مدحت محهد متحهود أبو النصر مودى

• أ أ.د. أ.د. مصطيلى محهد البغدادي السيد الطوخي مثهان عبد اللطيف عزمي 
- الهيئة الاستشارية العربية والدولية وفقًا للتر تيب الهجائي:

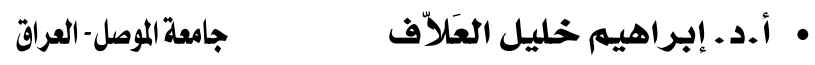

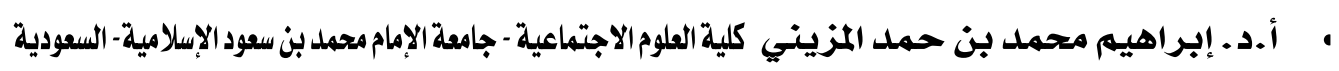
جامعة مؤتة- الأردن

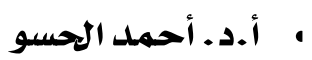
مركز الهسو للدراسات الكميةوالتراثية - إنجلترا

جامعة الملك سعود - السعودية

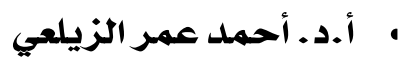
الأمين العام لجمعية التاريخ والآثار التاريخية كلية التربية للبنات - جامعة بغداد - العراق • أ.د. عبد الله حميد العتابي جامعة أم القرى - السعودية

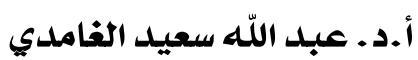

عضو مجلس كلية التاريخ، ومركز تحقيق التراث بععهل المخطوطات

$$
\text { جامعة الكويت- الكويت }
$$

رئيس قسم الماجستير واللدراسات العليا - جامعة تونسر - تونس الكوبت

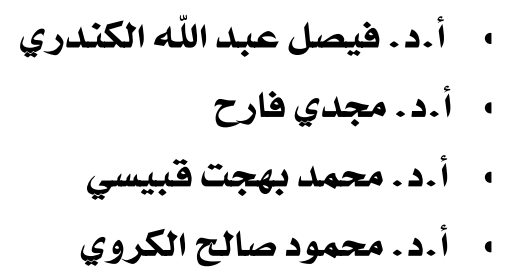

كلية العلوم السياسية - جامعة بغداد- العراق

- Prof. Dr. Albrecht Fuess

- Prof. Dr. Andrew J. Smyth

- Prof. Dr. Graham Loud

- Prof. Dr. Jeanne Dubino

- Prof. Dr. Thomas Asbridge

- Prof. Ulrike Freitag
Center for near and Middle Eastem Studies, University of Marburg, Germany Southern Connecticut State University, USA

University Of Leeds, UK

Appalachian State University, North Carolina, USA

Queen Mary University of London, UK

Institute of Islamic Studies, Belil Frie University, Germany 


\section{VI محتوياث العدد}

الصفحـــة

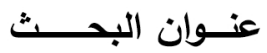

الدراسات التاريخية:

ا - الحروب الصليبية في كتابات المؤرخين الإماراتيين النماذج

$r \cdot-r$

مختارة إن

أ.د. محمد مؤنس عوض

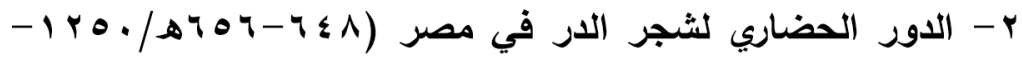

q. - r

$($ ) $r \circ V$

الباحثة/ أسماء يوسف عبداله البلوشي

الدراسات القانونبة:

Tr r - نظراث حول مفهوم الطرف فى العقد الباحث// محمد عبد القتاح عبد العظيم

؟ - السياسة الجنائية للوقاية من الأمراض المعدية الدراسة

$r \mid \leq-1 T V$

تحليلية مقارنة

مستشار دكتور / محمد جبربل إبراهيم

• الدراسات الفنية:

ه - ثقافة التعبير الرقمي في تقانة التثكيل التحتي المعاصر

$r \varepsilon T-Y I V$ 《دراسة تحليلية

م.د. أباذر عماد محمد صسادق البخدادي

\- دور الكفايات التعليمية لتحقيق جودة أداء التدريسي في قسم

TVT - r $\varepsilon V$

التربية القنية

أ.م.د. كريم حواس علي \& م.م. أسامة حسن عبد علي

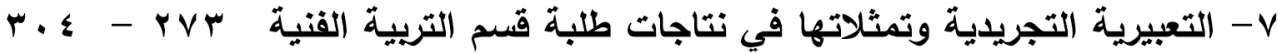

م.م. أثير عباس جواد

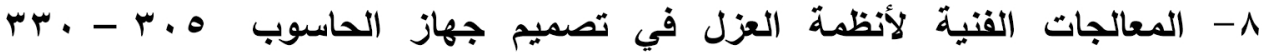
الباحث/ مصعب حسن عبد 


\section{VI تابع محتويات العدد}

الصفحـــة عنــوان البحــــث

9 - فاعلية استخدام الثخصيات الرمزية في الإعلانات الصحفية 》دراسـة rus - M

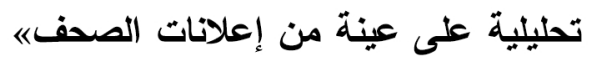

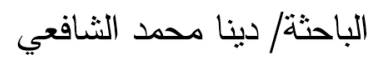

• 1- تحليل السلم الدياتوني في تنظير بنية الأنظمة السلمية

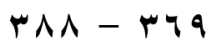
الموسيقية المختلفة .

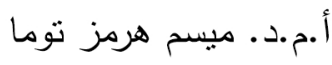
مالدراسات البيئية:

1 ا 1 - أثر القيادة الإدارية في تتمية الموارد البشرية لتحقيق التتمية المستدامة $\leq r \wedge-r q 1$

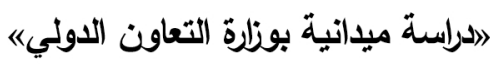
د. محاسن السبد نصر محمود جاد r ا - خطة استراتيجية مقترحة لدور الأمن البيئي للهيئة العامة $\varepsilon \vee \wedge-\varepsilon \mu q$ للاستعلامات الباحث/ هشام عبدالخالق سعد 


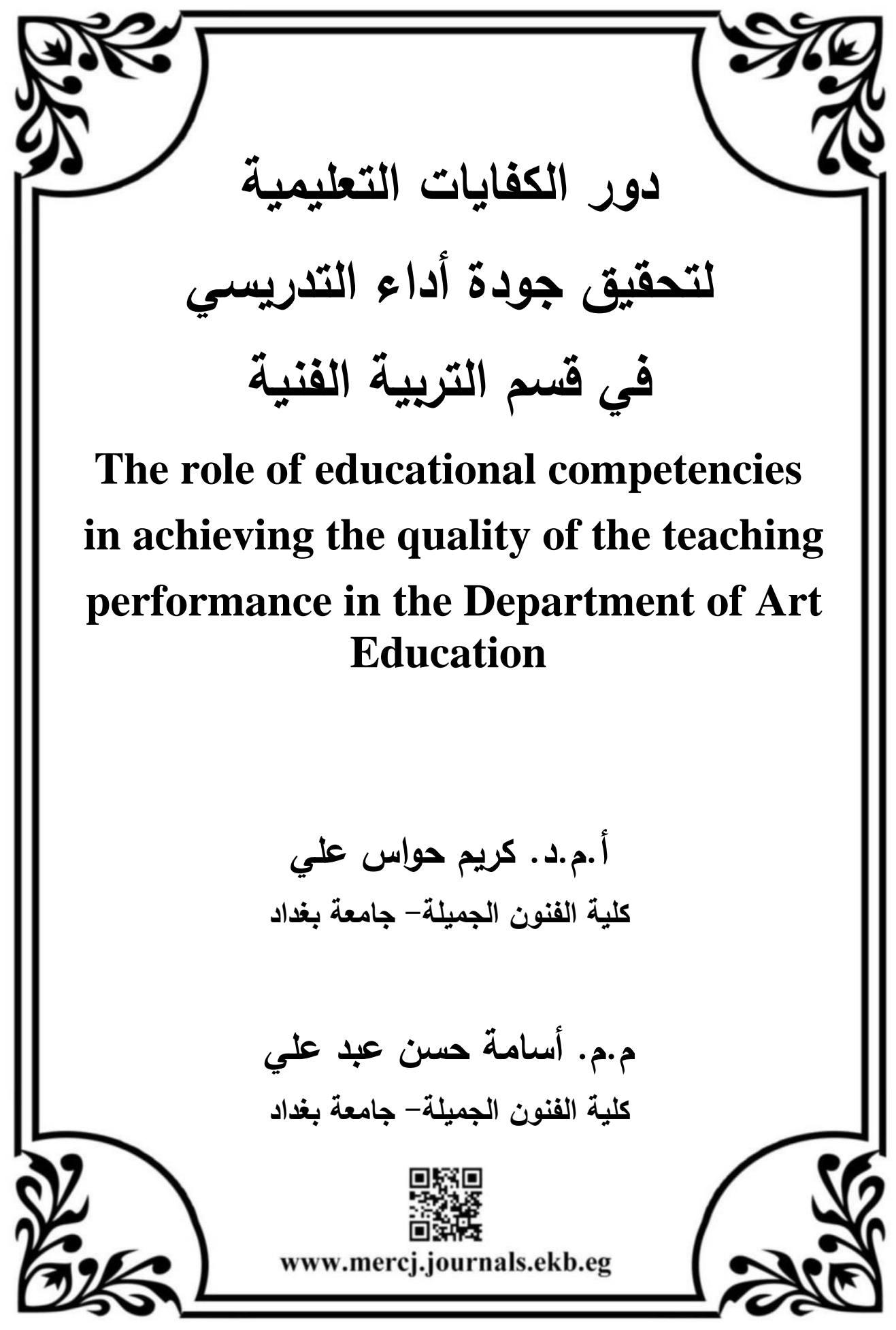



حاول الباحثان معالجة الإثكالية الآتية:(ما الدور الذي تؤديه الكفايات التعليمية في تحقيق جودة أداء تدريسي قسم التربية الفنية؟). لذللك هدف البحث الحالي إلى الكثف عن دور الكفايات التعليمية في تحقيق جودة أداء تدريسي قسم التربية الفنية؟.

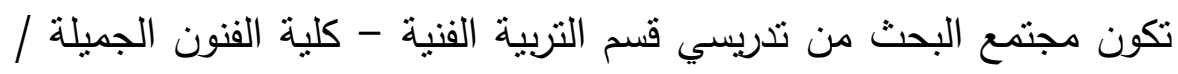

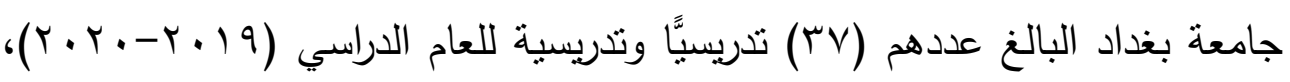

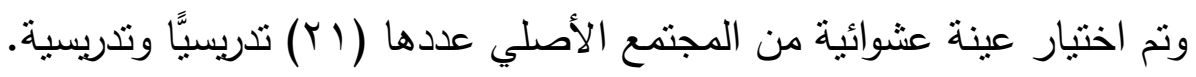

لتحقيق هدف البحث، استخدم الباحثان الإستبانة كأداة للبحث، تضمت

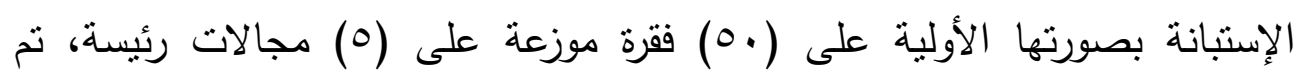

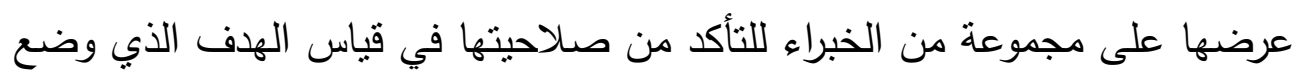

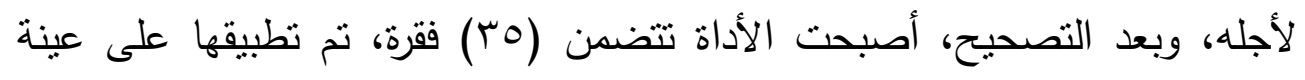
البحث، وقد خرج البحث بمجموعة من الاستنتاجات أهمها:

1-ظهور مؤشرات إيجابية ندل على وعي التدريسي بالأهداف التعليمية للمادة

الدراسية التي يقوم بتدريسها ضمن المرحلة الدراسية المقررة لها. r-ظهور مؤشرات متوسطة في قيمها ندل على أن التدريسي في قسم التربية

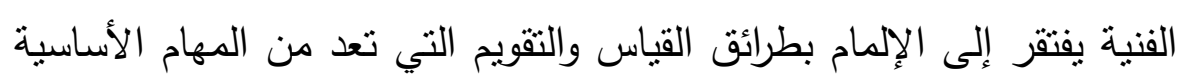
في عملية التدريس. 


\section{Abstract:}

The current research attempted to address the following problems: (What role does educational competencies play in achieving the quality of teaching performance of the Department of Technical Education?

Therefore, the aim of the current research is to reveal the role of educational competencies in achieving the quality of the teaching's performance of the Department of Art Education.

The research community consisted of (37) faculty members of the Department of Art Education - College of Fine Arts / Baghdad University, for the academic year (2019-2020), and a random sample of (21) faculty members was taught and taught.

To achieve the research goal, the researchers used the questionnaire as a research tool. The questionnaire included in its initial form on (50) paragraphs distributed in (5) major areas, which were presented to a group of experts to ensure their suitability in measuring the goal for which it was set, and after the correction the tool now includes (35) paragraphs. It was applied to the research sample, and the research came out with a set of conclusions, the most important of which are:

1-The emergence of positive indicators indicating the teaching's awareness of the educational goals of the academic subject he is teaching's within the prescribed academic stage.

2- The emergence of intermediate indicators in their values that indicate that the teaching staff in the Department of Art Education lacks familiarity with the methods of measurement and evaluation, which are among the basic tasks in the teaching's process. 
يعد دور التدريسي في الجامعات مهمًّا جدًا في تتظيم وتيسبير تعليم الطلبة من خلال البرامج والإستراتيجيات التي يتبعها في العملية التعليمية، وهذا يعتمد على دولى مدى امتلاكه للكفايات التعليمية المتتوعة، والتي يمكن أن تؤثز على جودة الأداء من أجل نجاح مهامه في عملية التدريس، وتحقيق الأهداف المخطط لها مسبقًا، فضلًا عن عدم تقبل بعض التدريسيين لأساليب التطوير والتحسين، كونها نتطلب منهم

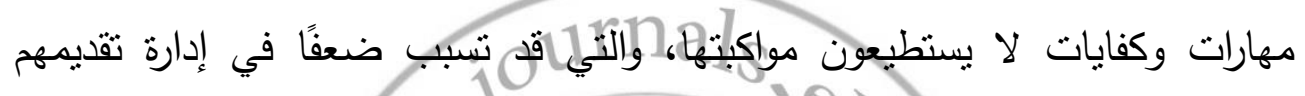

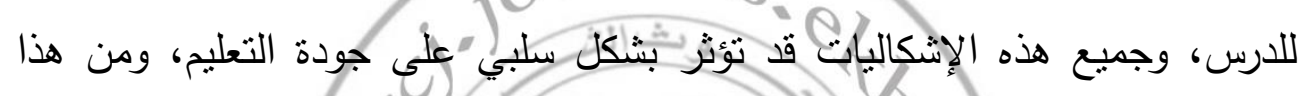
المنطلق، يتعين ضبط ونحديد معايير وشروط نطبيق جوأدة أداء التذريسي على مستوى المؤسسات التعليمية بشكلها العام، وفي جامعة بغداد/ كلية الفنون الجميلة/ قسم التربية الفنية بشكلٍ خاص، لضمان تطبيقه بصورة أمنل وفقًا للاور الذي تلعبه الكفايات التعليمية للتدريسي، كون أن هذه الكفايات تعد حجر الأساس لأدائه داخل

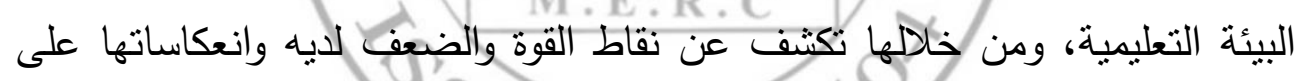
العملية التربوية، إن معرفة الكفايات التبربسية ثُطيهر أهمية رسالة التدربسي وخصوصيتها المهنية وضرورة تحديد مقياس مهني، وهذا ما تطرقت اليه دراسات

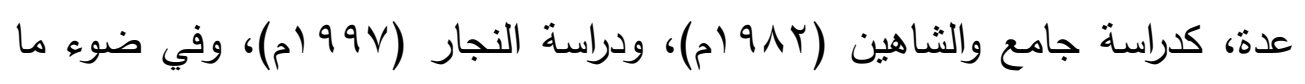
طرح، تحاول هذه الدراسة معالجة الإشكالية الآتية:(ما الدور الذي تؤديه الكفايات التعليمية في تحقيق جودة أداء تدريسي قسم التربية الفنية؟). 
ا- قد يساعد التعرف على الكفايات التعليمية للكوادر التدريسية، في الكثف عن نواحي القوة والضعف لديهم في عملية التدريس الصفي. r- قد يستفيد مدرسي التربية الفنية في كلية الفنون الجميلة في التوجه نحو النقد الذاتي لأدائهم التدريسي من خلال إطلاعهم على معايير الجودة في التعليم. r- قد تفيد الدراسة في تحسين المادة التعليمية وتطوير أداء الكوادر التدربسية. ع - الكثف عن الكفايات التعليمية للمدرس له دور مهم في تحسين وتطوير النظام التعليمي الجامعي، ليتلاءم مع مفهوم جودة الأداء التعليمي. 0-الدور الذي يلعبه البحث الحالي في عملية التقويم الثامل للمؤسسات التعليمية، وبرامجها، طبقًا للمعايير القياسية في جودة التعليم. ج-يوفر البحث الحالي فرصًا تعليمية متميزة للجميع وسعيه إلى تحقيق مخرجات عالية الجودة..

V- يسعى البحث الحالي إلى تطوير أساليب الأداء بتحديث طرائق تدريسية تقوم على أساس التقاعل بين الذوات المشاركة في العملية التعليمية، وربط التعليم بالمهارات الحياتية وإدارة الحياة، واحنياجات المجنمع المحلي.

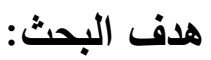
الكثف عن دور الكفايات التعليمية في تحقيق جودة أداء تدريسي قسم التربية

الفنية؟ حدود البحث: مدرسو ومدرسات المواد الدراسية (النظري والعملي والتطبيقي) المقررة في قسم التربية الفنية- كلية الفنون الجميلة- جامعة بغداد/ الدراسة الصباحية، للعام الدراسي: $\cdot r \cdot r \cdot-r \cdot 19$ 


\section{تحديا المصطلحات:}

ا- الكفايات ما هي إلاَّ الأهداف السلوكية المحددة تحديدًا دقيقًا والتي تصف كل المعارف والمهارات والاتجاهات التي يعتقد أنها ضرورية للمعلم إذا أراد أن يعلم تعليمًا فعالًا، أو أنها الأهداف العامة التي تعكس الوظائف المختلفة التي على المعلم أن يكون المعلم قادرًا على أدائها".

ץ- عرفت باتربسيا(Kay.M Patricia) الكفاية التعليمية بأنها: "مجموعة الأهداف السلوكية المحددة تحديدًا دقيقًا والتي تصف كل المعارف والمهارات والاتجاهات التي يعنقد أنها ضرورية للمدرس إذا أراد أن يعلم تعليمًا فعالًا، أو أنها الأهداف التعليمية التي تعكس الوظائف المختلفة التي على المدرس أن

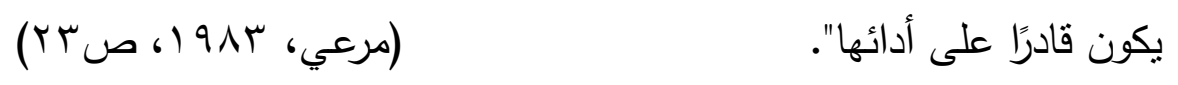

ب-الجودة: عرفها (الرشيد، 990 (م) بإنها:" مفهوم تعليمي كونه يتعلق بكافة السمات والخواص المرتبطة بالمجال التعليمي والتي تظهر جودة النتائج المراد تحقيقها، كما إنه ترجمة احتياجات توقعات الطلبة إلى خصائص محددة تكون أساسًا في تعليمه وتدريبهم، وصياغتها في أهداف تعليمية وسلوكية بما بوافق

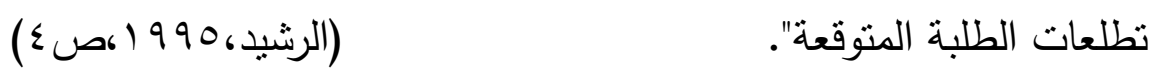
إذ تبنى الباحثان هذا التعربف لملائمته في تحقيق هدف البحث وإجراءاته.

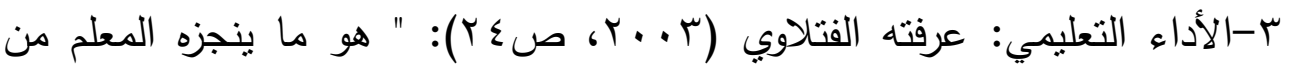

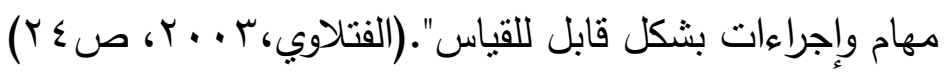

إن هذا التعريف أفاد الباحثان في صياغة تعريف إجرائي يتلاءم مع هدف واجراءات بحثهما، هو : (ما ينجزه تدريسيو المواد المقررة في قسم التربية الفنية / كلية الفنون الجميلة من مهام تعليمية وتدريسية قابلة للقياس على وفق معايير الجودة). 
الفصل الثاني

الإطار النظري

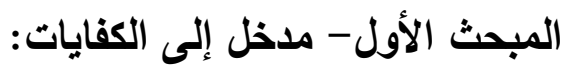

"اتُعد الكفايات إحدى المفاهيم التعليمية المعاصرة، فقد ظهر أول برنامج لتدريب المدرسين على الكفايات في الولايات المتحدة الأميركية عام 97 ام؛ لأن المفهوم ارتبط بإتقان أداء التدريسي في المجال التعليمي، وأصبح مدخل الكفايات أحد الاتجاهات المعاصرة في إعداد المدرس وتدريبه، لذلك من الضروري تزويد التدريسيين بثقافة مهنية وتعليمية جديدة، والسعي للحصول على القدرات المطلوبة والكفايات اللازمة من قبل التدريسيين في تخصصاتهم التعليمية والتي تعمل على نجاحه وتطوره في مهنته في المستقبل، كما تساعد امتلاك التدريسيين لهذه الكفايات في تطبيق المعرفة وتوجيه سلوكهم الأدائي، توجهًا صحيحًا".

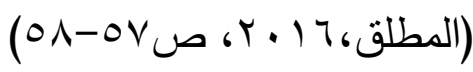

هنالك مجموعة من الكفايات التعليمية التي ينوجب على التدريسي من

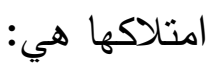

1- الكفايات التدريسية: تمنل هذه الكفايات مجموعة من القدرات المعرفية والمهارية التي يمنلكها التدريسي ويمارسها في المواقف التعليمية، مما يمكنه من أداء مهامه التعليمية بفعالية وإتقان القدرة على تتفيذ الأنشطة التعليمية، والتي تقوم على سلسلة من الحقائق والمفاهيم والمبادئ، التي تتضح من خلال السلوك التعليمي الذي يصل إلى درجة المهارة. كما أثنار التربويون إلى توعية التدريسيين حول عملية تقويم التذريسي يمكن أن 
تحقق أهدافا متعددة، فمن الضروري المراقبة والتقييم المستمر لجميع العاملين في مجال التعليم للتأكد من القدرات المعرفية والمهارية التي يمتلكونها وتعزيز نقاط قوتهم وقدراتهم العلاجية؛ إذ يشير (المفلح) أن الأهداف التي تحققها عملية تقييم التذريسي هي:تحسين الكفايات التدريسية لاى التذريسي والثقة بالنفس، وضمان التطور العلمي لمجالاته المهنية. وضع معايير لمساعدة التدريسي على تحسين مستوى التدريس مقارنة بالتغيرات في المجتمع. القدرة على الحكم لتأهيل التدريسي للتقدم في مجال التعليم العالي من أجل تعزيز قدرتهم في مجال التعليم، إن تقويم كفاية التدربسي جاءت بناءً على سلوكه في مراقبة سلوكه الواضح، مما يعني الملاحظة الدقيقة للمهارات

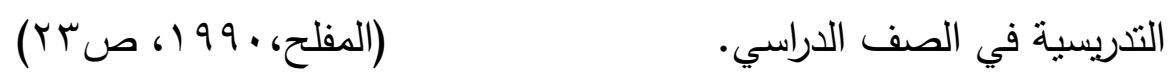
r- الكفاية المهنية: ترتبط بالعلاقة بين الوظيفة والتخصص، والاستفادة من الإعداد الأكاديمي الجامعي في التخصصات المهنية والعمل بإتقان والرغبة فيه. r- الكفاية الأكاديمية: ابتداءً من المعرفة الواسعة في المجال التخصصي، الاطلاع على التطورات العلمية الحديثة، كذلك على دراسات وأبحاث علمية عديدة، متابعة الاجتماعات والمناقثات الجماعية في مجال العمل، والتحدث باللغة العربية بطلاقة، وإتقان مهارات العمل بالحاسوب.

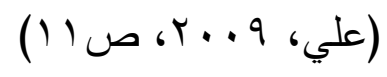

ع-كفايات الاتصال والتواصل: القدرة على التواصل مع الآخرين وقبول آراء الآخرين ومهارات المناقثة والحوار •

ه-الكفايات الثخصية: تتضمن مجموعة من القدرات التي يتمتع بها التدريسي 
منها التعاون والعمل بفعالية في فريق العمل وإدارة الوقت بشكل فعال وحل المشكلات بسرعة والتعبير عن أفكار مبتكرة وعلى اتخاذ القرارات بطريقة علمية وعلى تحمل المسؤولية.

צ- الكفاية اللغوية: يعد (نوام تشومسكي Noam Chomesky) أول من استخدم مصطلح الكفاية اللغوية؛ إذ إنه وضع ثثائيته المشهورة المتمثلة في (الكفاية Compétence) بو(الأداء Performance) وهي تمنل الدعامة الأساسية Ferdinand للنظرية اللسانية عنده، فقد استفاد من ثثائية (فردينان دي سوسير (de Saussure) القائمة بين اللغة والكلام، كما عرف (تشومسكي Chomesky) الكفاية اللغوية على أنها " قدرة المتكلم- المستمع المثالي - على أن يجمع بين الأصوات اللغوية وبين المعاني في تتاسق وثيق مع قواعد لغته"، إذ إن اللغة ليست مجرد أصوات، إنما القدرة على ربط الأصوات اللغوية والمعاني التي تؤديها، والتي تكون منتاسقة مع قواعد لغته؛ وبتعبير آخر، فإن الكفاية اللغوية هي نتاج يسمح للمنكلم بفهم عدد لا متتاه من الجمل الجديدة، حتى لو لم يسبق له سماعها من قبل، وذلك انطلافًا من عدد محدود من الوحدات الصوتية، وهذا للتعبيرعن الأفكار والدلالات، كما تسمح له أن يستدعي إحاطة السامع والمنكلم” بالتمبيز بين الجمل من حيث صحتها نحويًّا، ملمًا بأنظمة اللغة ومستوياتها المختلفة (صونية، صرفية، تركيبية ودلالية).

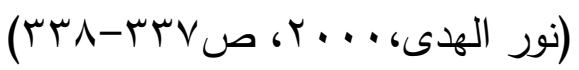

r-الكفاية التواصلية: يُعد (ديل هايمز Dell Hymes) أول من تحدث عن مفهوم الكفاية التواصلية في دراسة نشرت له عام اله ام، والتي كانت استجابة لأفكار (تشومسكي Chomesky) حول الكفاءة والأداء؛ إذ وجد أنها معزولة عن أبي بيئة تستخدم فيها العملية التواصلية، ويعتقد (هايمزأHymes) أن المتحدثين بلغات معينة يجب أن يتمكنّا من قوانينها من ناحية، وأن يكونوا قادرين على استخدامها 


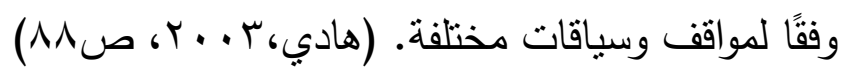

كما برى (ساندرا سافجنون Sandra Savignon) أن للكفاية التواصلية

$$
\text { سمات أو خصائص معينة تتمنث فيما بأني: }
$$

ا- إن الكفاية التواصلية مفهوم متحرك dynmic، وليس ساكنا static أنه بعتمد

على مدى قدرة الفرد على تبادل المعنى مع فرد آخر أو أكثر، أنها إذن علاقة شخصية بين طرفين interpersonal أكثر من أن تكون اتصالًا ذاتنًا

$$
\text { intrapersonal }
$$

r- تتطبق الكفاية التواصلية لكل من اللغات المنطوقة والمكتوبة.

ب- إن الكفابة التواصلية نسبية وليست مطلقة، ومن هنا بمكن التحدث عن درجات

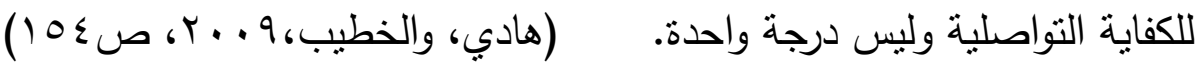
أكدت معظم الأبحاث التربوية في مجال التعليم أن نجاح التدريسي في تحقيق أهداف التعليم والتعلمي بعتمد إلى حد كبير على طبيعة التواصل والتواصل بين المدرس والمتعلمين وبين الطلبة فيما بينهم، ومن أجل تحقيق هذا النوع من التواصل، هنالك حاجة إلى بيئة تفاعلية مناسبة ومشجعة، وجميع الأنشطة المطلوبة من فبل المعلمين والطلاب تحتاج إلى التواصل المستمر مع التفاعل في الصف الدراس، ويطلق على هذه الأنشطة بـ (التفاعل الصفي).(الخطابية وآخرون، ع . . ب، صع ؛ 1)

\section{المبحث الثاني - مفهوم الجودة التعليمية:}

يُعد مفهوم الجودة من المفاهيم المعاصرة يقوم على مجموعة من الأفكار والمبادى التي بمكن أن تطبقها أي مؤسسة لتحقيق أفضل أداء وتحسبن مخرجاتها وسمعتها الداخلية والخارجية.

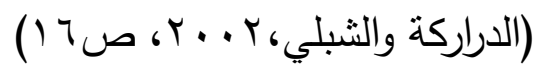


للجودة أهمية كبيرة في العملية التعليمية بمكن توضيحها في الفقرات الآتية: تحسين مستوى الطلبة في جميع الجوانب البدنية والنفسية والاجتماعية والعقلية. تحسين مؤهلات التدريسيين والعاملين في المؤسسات التعليمية ورفع مستوى أدائهر. زيادة التقة والتعاون بين المؤسسات التعليمية والمجتمع. توفير مناخ التفاهم والتعاون بين جميع العاملين بالمؤسسات التعليمية. تتمكن المؤسسة التعليمية من خلال تطبيق نظام الجودة كسب الاحترام والتقدير

$$
\text { والاعتراف العالمي. }
$$

خلق بيئة تعليمية تدعم التطوير المستمر •

وجود نظام شامل ومدروس ينعكس إيجابيًّا على سلوك الطلبة، وتحقيق منافسة

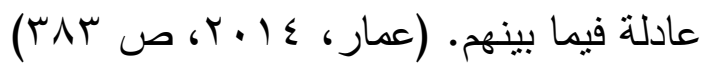

تحسين طرق التدريس وتطويرها بما يتوافق مع المناهج المعاصرة.

تتمية مهارات وقدرات الكادر التدريسي والعاملين في المؤسسة التعليمية من خلا التدريب المستمر ومواكبة التطور الذي تشهده المؤسسات التعليمية في الدول المتقدمة.

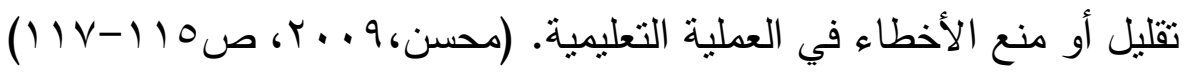
وللجودة أهداف متعددة في المجال التعليمي، هي:1-تعديل وتظوير النظام الإداري وتحديد الأدوار والمسؤوليات.

ץ-ضرورة تحسين المستوى الأكاديمي، الاجتماعي، النفسي، التعليمي لدى المتعلمين؛ لأنهم من أهم مخرجات النظام التعليمي. r-تحسين مستوى وعي المتعلمين اتجاه العملية التعليمية وأهدافها. 
ع-ضرورة التدريب المستمر، لزيادة قدرات وكفايات جميع العاملين في المؤسسات التعليمية، وتوفير جو من التفاهم والتعاون فيما بينهم من أجل التحسين والتطوير المستمر لتحقيق نتائج تعليمية تتافسية..

ه-يجب أن يساهم في تتمية المجتمع المحلي والنهوض به، والحصول على احترامه وتقديره، والاعتراف به من قبل مؤسساته التعليمية لمختلف الخدمات

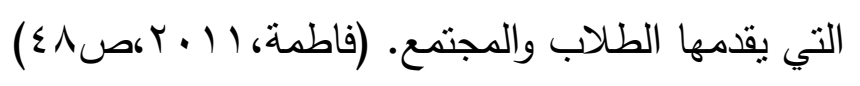

لتطبيق الجودة في التعليم لابد من المرور بعدة مراحل رئيسة، التي تُعد

$$
\text { متطلبات رئيسة في تطبيق الجودة كما ذكرها (عليمات)، وهي: }
$$

أولًا مرحلة اقتتاع وتبني الإدارة لفلسفة إدارة الجودة الثاملة: حيث تبدأ الإدارة

$$
\text { بتلقي برامج تدريبية متخصصة في هذا الجانب. }
$$

ثانيًا- مرحلة التخطيط: إذ يتم وضع الخطط التفصيلية للتففيذ وتحديد الهيكل الدائم

$$
\text { والموارد اللازمة لتطبيق هذا النظام. }
$$

ثالثًا - مرحلة التقويم: غالبًا ما تبدأ هذه العملية بتساؤلات مهمة والتي يمكن في الإجابة عليها تهيئة الأرضية المناسبة للبدء في تطبيق الجودة.

رابعًا- مرحلة التنفيذ: اذ يتم اختيار الأفراد الذين سيعه إليهح بعملية التنفيذ ويتم

$$
\text { تدريبهم على أحدث الوسائل المتعلقة بإدارة الجودة. }
$$

خامسًا - مرحلة تبادل ونشر الخبرات: إذ يتم استثمار الخبرات والنجاحات التي تم

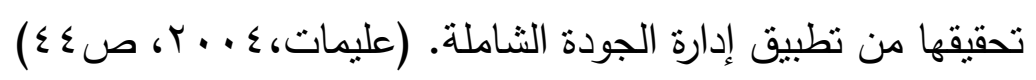

\section{المبحث الثالث- - مفهوم الأداء والتوجهات المتعددة في طرحه:}

أصبح مفهوم الأداء مفهومًا متميزًا؛ لأنه يجمع بين الكفاءة والفعالية مع الأع العاء الأحكام الإيجابية أو السلبية للمؤسسات التعليمية، كذلك درجة قدرتها على تحقيق 
الأهداف، والتي عادة ما تترجم من قبل المؤسسات إلى مقاييس متعددة الأبعاد، تسعى جاهدة إلى بنائها بطرق مختلفة وتحويلها إلى أداة تقييم حتى تتمكن من النظر إلى

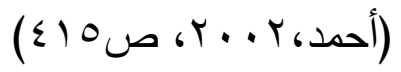
نفسها بشكل صحيح.

إن فهم الأداء لن يتم أبدًا إلا بعد التعرف على هذين المتغيرين وهما (الكفاءة) و(الفعالية) اللذان يعدان من أكثر المفاهيم المرتبطة بالأداء ويعد العديد من لاءن لهن الباحثين بأن الكفاءة والفعالية هما البعدان الرئيسان له.

لذلك يجد (الباحثان) بأن البعض يرى أن الفعالية أشنمل وأوسع من الكفاءة،

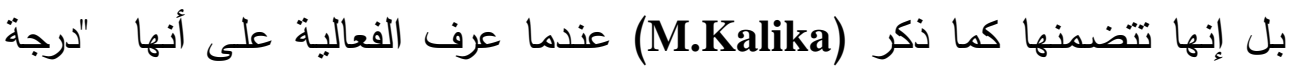
تحقق الأهداف المسطرة من طرف المؤسسة"، بهذا المفهوم، فإن الفعالية أوسع من الكفاءة بل إنها تتضمنها بشكل واضح مع الفكرة التي تتظر إلى الفعالية والكفاءة على الى أنهما جسم واحد لا ينفصل، ويكون الفصل في هذا الموضوع بالقول أن لكل من الكفاءة والفعالية جزءًا يتمم الآخر، فالفعالية هي فعل للأشياء الصحيحة، أما الكفاءة، فهي فعل الأشياء بالشكل الصحيح. (Cohen, 2000, p:131) كما إنهما يتفاعلان معا لينتجا الأداء بمفهومه الكامل وهو (البحث عن أفضل مخرجات وفي نفس الوقت تحقيق نمو دائم) (Fernandez, 2000, p:41). كذلك، إن البحث في سبيل تطوير وتحسين الأداء الجامعي من خلال جودة الكلية أو الجامعة يجب أن يأخذ بنظر الاعتبار جميع الأليات التي من شأنها أن تضيف تحسينات إلى الأداء سواء كانت من خلال عضو هيئة التذريس أم المتعلم باعتباره أحد أهم مخرجات الجامعة أو على صعيد خدمات المجتمع المقدة من الجامعة وتقتضي معرفة جودة العملية التعليمية الجامعية ابتداءً من تحليل هذه العملية وتحديد مكوناتها والعلاقة التفاعلية بين هذه المكونات؛ لأنها يفترض أن تشكل الأساس المككن اعتماده في تشخيص وتحديد متطلبات التحسن، كما تعددت تطبيقات تحسين 
الأداء بتعدد أنشطة الجودة التعليمية التي يمارسها المدرس في المؤسسات التعليمية.

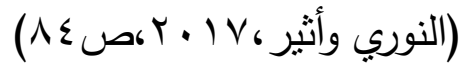

إن جودة الأداء المتوقع من المدرس والذي يتوجب عليه القيام به يتمحور حول تمكنه من تقديم جودة التعليم الجديدة التي يفرضها مجتمع المعرفة؛ لأن هذا بتطلب من لن المدرس تغيير دوره من كونه مرسلًا للمعلومات إلى موجه ومنظمًا لبيئة التعلم. لذلك أعطاهم تدربيَّا علميَّا في التفكير وحل المشكلات وكيفية صياغة أساليب الحصول على المعلومات من المصادر الرئيسة وتوجيههم لتعلم المعرفة العلمية من خلال الاعتماد على الذات، وكل ذللك يكمن فيما يتمتع به المدرس من خبرة وكفاءة وصلاحية للتواب والعقاب. (درباس،ء99 (،ص.ب٪) كما إن معايير جودة أداء المدرس الجيد تثمثل بالمجالات الآتية:

1-مسؤوليات المدرس عن طلبته وعن تعلمهم: هي مسؤولية المدرس في تسهيل أمر طلبته في حصولهم للمعرفة وتعديل ممارساته في ضوء ميول طلبته وقدراتهم ومهاراتهم.

ץ-معرفة المدرس للموضوعات الدراسية التي يُعلمها لطلبته: هي إلمام المدرس بموضوع الدرس ضمن المنهج المتبع، بما بتتاسب مع معارف ومدركات الطلبة ومفاهيمهم السابقة واختيار مسارات معرفية متعددة تتتاسب مع الفروق الفردية بين الطلبة.

ب-مسؤوليات المدرس عن إدارة تعلم طلبته ومراقبتهم: نعني بها قدرة المدرس على اختيار الاستراتيجيات والأساليب التعليمية إضافة إلى الأنشطة المتعددة التي تتاسب ميول طلبته وقياس نموهم المعرفي وتقدمه في التعلم. ع- القدرة على التفكير المنظم في ممارساته والتعلم والنمو المهني من خلا الخبرة: إن المدرس المهني يملك القدرة على / والرغبة في فحص ومحاكمة

rฯ $\quad$ Forty - eighth year - Vol. 71 January 2022 
ممارساته بطريقة ذاتية، ويسعى للحصول على المشورة من الآخرين وزيادة معرفته من خلال الإفادة من الأبحاث التربوية، وتطوير ممارساته بما يتلاءم

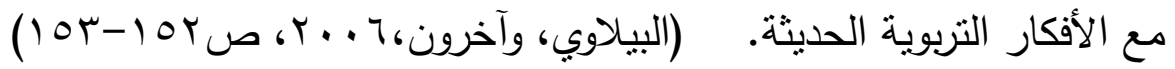

\section{الفصل الثالث}

\section{منهجية البحث وإجراء|ته}

اعتمد الباحثان المنهج الوصفي لملاعمته طبيعة البحث.

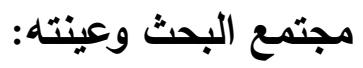

ضم مجتمع البحث تدريسي قسم التربية الفنية - كلية الفنون الجميلة / جامعة

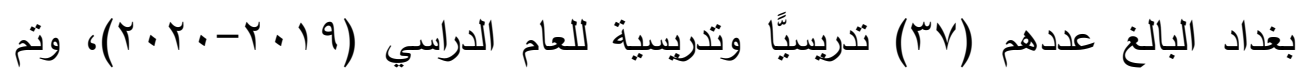
اختيار عينة عشوائية من المجتمع الأصلي للاراسة عددها (Y) تدريسي وتدريسية.

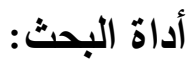

استخدم الباحثان الإسنبانة كأداة لإتمام متطلبات البحث، وقام الباحثان ببناءالإسنتانة من خلا الاستعانة بالأدبيات والدراسات السابقة التي تتاولت موضوع الكفايات التعليمية، تضمت الإستبانة بصورتها الأولية على (.0) فقرة موزعة على (0) مجالات رئيسة.

لتحقيق صدق الأداة، قام الباحثان بعرض الإستبانة بصورتها الأولية على (1) (1) محكمين في اختصاص في التربية الفنية وطرائق التّريس والقياس والتقويم، كما

$$
\text { موضح في الجدول (1): (1) }
$$


دور الكفايات التطيمية لتحقيق جودة أداء التتريسي في قسم التربية القنية أ.م.د. كريم حواس علي \& م.م. أسامة حسن عب علي

جدول (1)

قائمة بأسماء الخبراء للتعرف على صلاحية فقرات الإستبانة

وقد أبدوا الخبراء بعض الملاحظات على فقرات الإستبانة، على ضوئها تم

\begin{tabular}{|c|c|c|c|}
\hline جامعة بغداد - مكان العمل والتخصص & اللقب العلمي & الغبير & $ت$ \\
\hline جامعة بغداد-كلية الفنون الجميلة_طرائق تدريس & 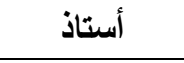 & ل د. ماجد نافع الكناني & 1 \\
\hline جامعة بغداد - كلية الفنون الجميلة_طرائق تدريس & أستاذ & د. صالح أحمد الفهداوي & r \\
\hline جامعة بغداد - كلية الفنون الجميلة _ تربية فنية & 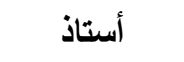 & د. عبد المنعم خيري & $r$ \\
\hline جامعة بغداد - كلية الفنون الجميلة _تربية فنية & أستاذ & لد. رعد عزيز عبدالله & $\varepsilon$ \\
\hline جامعة بابل - كلية الفنون الجميلة - تربية فنية & 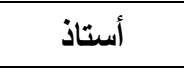 & د.فاطمة لطيف عبدالله & 0 \\
\hline هيئة التعليم التقتي _ طرائق تدريس الفنون & 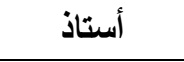 & د. منير فخري الحديثي & 7 \\
\hline كلية تربية ابن رشد- قياس وتقويم & 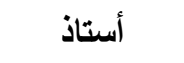 & 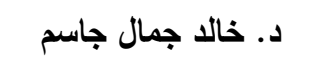 & 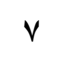 \\
\hline جامعة بغداد - كلية الفنون الجميلة _ تربية فنية & 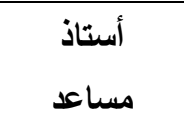 & د. هيلا عبد الثهيد & $\wedge$ \\
\hline الجامعة المستنصرية- كلية التربية الأساسية- تريبة & 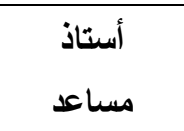 & ل د. سهاد جواد الساكني & 9 \\
\hline جامعة بابل - كلية الفنون الجميلة - تربية فنية & 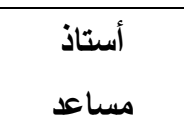 & 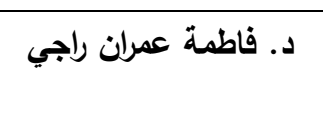 & 1. \\
\hline الجامعة المستتصرية - كلية التربية- قياس وتقويم & 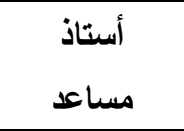 & د. أمل اسماعيل عايز & 11 \\
\hline
\end{tabular}

إجراء بعض التعديلات، لتصبح جاهزة للتطبيق، لتتضمن الإستبانة بصورتها النهائية على (rr) فقرة موزعة على (0) مجالات كما موضح في الجدول (r): 
جدول (r)

يبين مجالات الإستبانة المتضمنة الكفايات التعليمية لتدريسي التربية الفنية

\begin{tabular}{|c|c|c|}
\hline عدد الفقرات & مجالات الكفايات التعليمية & ت \\
\hline 5 & كفايات الأهداف التعليمية & 1 \\
\hline 7 & كفايات التخطيط & 2 \\
\hline 7 & كفايات التنفيذ & 3 \\
\hline 7 & كفايات طرائق التدريس & 4 \\
\hline 7 & كفايات التقويم & 5 \\
\hline
\end{tabular}

لإظهار معامل الثبات لأداة البحث، قام الباحثان بتطبيق الأداة على عينة البحث الاستطلاعية البالغة (1) (1) تدريسي وبعد مرور أسبوع، تم إعادة الاختبار على لإنى نفس العينة وباستخدام معامل ارتباط بيرسون، ومن ثم استخراج معامل الثبات والذي بلغ (^ᄉی, • ) وهي نسبة ثبات جيدة.

\section{التجرية الاستطلاعية:}

لغرض الوقوف على السلبيات التي قد نرافق البحث قام الباحثان بإجراء التجربة الاسنطلاعية على (0) من تدريسي التربية الفنية خارج عينة البحث. الوسائل الإحصائية: الوسط المرجح - درجة الحدة - الوزن المئوي - معامل ارتباط بيرسون. 


\title{
الفصل الرابع
}

\section{عرض النتائج وتفسبرها}

تم تطبيق أداة البحث على العينة الأساسية من التدريسيين والتدريسيات في قسم التربية الفنية البالغ عددهم (Y) تدربسيَّا وبعد جمع الاستمارات منهم تم إظهار النتائج المبينة في الجدول (r).

\author{
جلول (r)
}

يبين كفاية تدريسي التربية القنية ضمن مجال الأهداف

\begin{tabular}{|c|c|c|c|c|c|c|}
\hline \multirow{2}{*}{ المئوي } & \multirow{2}{*}{ الحدة } & \multicolumn{3}{|c|}{ أمارسـها بلرجة: } & \multirow{2}{*}{ كفايات مجال الأهداف } & \multirow{2}{*}{ ت } \\
\hline & & ضعيفة & إلى حـ ما & كبيرة & & \\
\hline 0,94 & 2,80 & - & 4 & 17 & العمل على تعزيز القيم الأخلاقية في نفوس الطلبة. & 1 \\
\hline 0,86 & 2,57 & 3 & 3 & 15 & القيام بتتمية الميول والرغبات لدى الطلبة. & 2 \\
\hline 0,87 & 2,62 & 2 & 4 & 15 & القيام بتتمية روح التواصل الاجتماعي بين الطلبة. & 3 \\
\hline 0,92 & 2,76 & 2 & 1 & 18 & حث الطلبة على الالنزام بالنظام وتحمل المسؤولية. & 4 \\
\hline 0,84 & 2,52 & 3 & 4 & 14 & القيام على تدريب الطلبة على ممارسة الأنشطة المتتوعة. & 5 \\
\hline
\end{tabular}

من خلال النظر إلى نتائج الجدول (r) يتنين للباحثين أن درجات الحدة

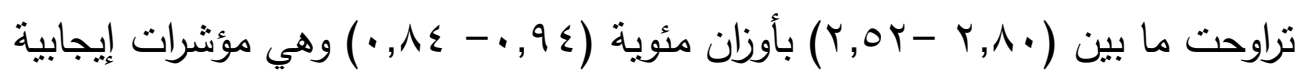

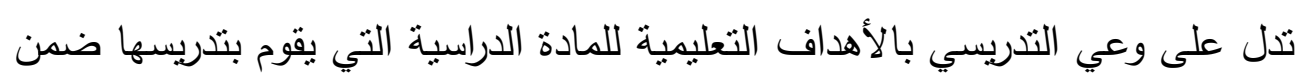
المرحلة الدراسية المقررة لها. 
جدول (๕)

يبين كفاية تدريسي التربية الفنية ضمن مجال التخطيط

\begin{tabular}{|c|c|c|c|c|c|c|}
\hline \multirow[b]{2}{*}{ 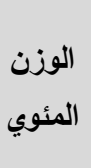 } & \multirow{2}{*}{ 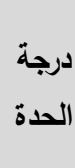 } & \multicolumn{3}{|c|}{ 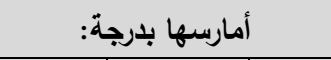 } & \multirow[b]{2}{*}{ كفايات مجال التخطيط } & \multirow[b]{2}{*}{$ت$} \\
\hline & & 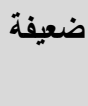 & إلى حد & كبيرة & & \\
\hline 0,79 & 2,38 & 3 & 7 & 11 & أعمل على تحليل الأهداف التعليمية إلى أهداف سلوكية. & 1 \\
\hline 0,83 & 2,48 & 3 & 5 & 13 & أقوم بتحدبد الإجراءات المناسبة لتحقيق الأهداف. & 2 \\
\hline 0,79 & 2,38 & 4 & 5 & 12 & أراعي تحديد موضوعات المادة الدراسية على وفق الأهداف & 3 \\
\hline 0,87 & 2,62 & 2 & 4 & 15 & اختار الأنشطة التعليمية التي تلائم قدرات الطلبة. & 4 \\
\hline 0,81 & 2,43 & 3 & 6 & 12 & اختار الوسائل والتقنيات الملائمة لموضوع الدرس & 5 \\
\hline 0,76 & 2,29 & 4 & 7 & 10 & أقوم بالتخطيط للادس تحقيقًا للأهداف الخاصة. & 6 \\
\hline 0,71 & 2,14 & 6 & 6 & 9 & أقوم بإعداد خطة سنوية لتتظيم المادة الدراسية. & 7 \\
\hline
\end{tabular}

من خلص النظر إلى نتائج الجدول (ع) يتنين للباحثني أن درجات الحدة تزاوحت ما

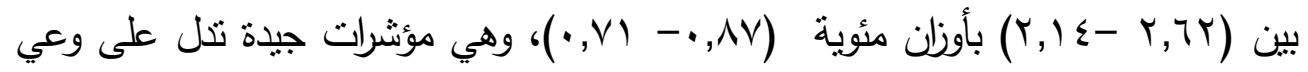
التشريسي بأهية التخطيط للمادة الدراسية التي يقوم بتربسها ضمن المرحلة الدراسية المقررة لها.

$$
\text { جدول (•) }
$$

\section{يبين كفاية تدريسي التربية الفنية ضمن مجال التنفيذ}

\begin{tabular}{|c|c|c|c|c|c|c|}
\hline \multirow{2}{*}{ المئوي } & \multirow{2}{*}{ درجة } & \multicolumn{3}{|c|}{ 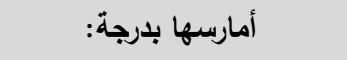 } & \multirow{2}{*}{ 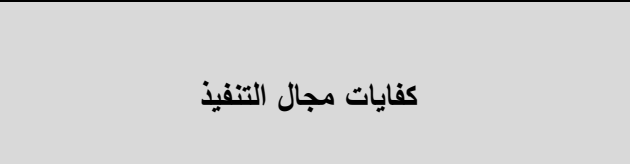 } & \multirow{2}{*}{$ت$} \\
\hline & & ضعيفة & إلى حد ما & كبيرة & & \\
\hline 0,87 & 2,62 & 3 & 2 & 16 & أراعي القدرات الفردية بين الطلبة. & 1 \\
\hline 0,86 & 2,57 & 2 & 5 & 14 & أقوم بتقديم المادة الدراسية بشكل واضح وبتسلسل منطقي. & 2 \\
\hline 0,70 & 2,10 & 8 & 3 & 10 & أستخدم أساليب تعليمية سمعية وبصرية ملائمة للطلبة. & 3 \\
\hline 0,70 & 2,10 & 7 & 5 & 9 & اتبع طريقة النمذجة عمليا في تدريس الطلبة. & 4 \\
\hline 0,77 & 2,33 & 4 & 6 & 11 & اوفر أتثطة تنطيبية في ضوء الإمكلت المنفوةفي القنم. & 5 \\
\hline 0,87 & 2,62 & 2 & 4 & 15 & اطرح أسئلة تتير التفكير لدى الطلبة. & 6 \\
\hline 0,83 & 2,48 & 5 & 1 & 15 & اعزز الأداء الجيد وتصحيح الخاطئ منه. & 7 \\
\hline
\end{tabular}


من خلال النظر إلى نتائج الجدول (0) يتبين للباحثين أن درجات الحدة

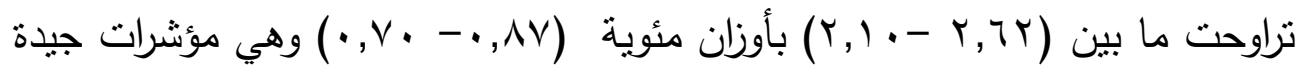
تدل على قدرة التدريسي بتنفيذ متطلبات المادة الدراسية التي يقوم بتدريسها ضمن المرحلة الدراسية المقررة لها.

جدول (7)

يبين كفاية تدريسي التربية الفنية ضمن مجال طرائق التدريس

\begin{tabular}{|c|c|c|c|c|c|c|}
\hline \multirow{2}{*}{ 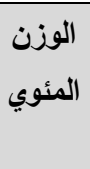 } & \multirow{2}{*}{ 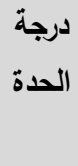 } & \multicolumn{3}{|c|}{ أمارسها بدرجة: } & \multirow[t]{2}{*}{ مجال كفايات طرائق التريس } & \multirow[t]{2}{*}{$ت$} \\
\hline & & ضعيفة & 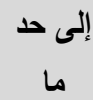 & كبيرة & & \\
\hline 0,69 & 2,09 & 6 & 7 & 8 & أستخدم الطرائق الحديثة في تعليم المهارات المتتوعة. & 1 \\
\hline 0,74 & 2,23 & 5 & 6 & 10 & أستخدم الطرائق التي تثير دافعية التعلم لدى الطلبة. & 2 \\
\hline 0,79 & 2,38 & 5 & 3 & 13 & التزبوية والتعليمية. تنويع أساليب التنريس على وفق الأهداف & 3 \\
\hline 0,84 & 2,52 & 4 & 2 & 15 & استخدم الطرائق التي تتيح للطلبة إبداء أرائهم بحرية. & 4 \\
\hline 0,85 & 2,57 & 2 & 5 & 14 & لتتخم الطرائق التي تنقد مبأ ألترجمن السطل إلى الصعب. & 5 \\
\hline 0,84 & 2,52 & 3 & 4 & 14 & اختار الطرائق التي تراعي الفروق الفردية بين الطلبة. & 6 \\
\hline 0,87 & 2,62 & 3 & 2 & 16 & الأنشطة التعليمية. الطئق التي توجه الطلبة نحو المشاركة في & 7 \\
\hline
\end{tabular}

من خلا النظر إلى نتائج الجدول (T) ينبين للباحثين أن درجات الحدة

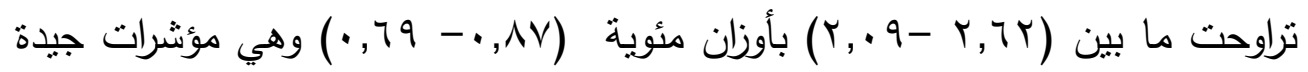
تدل على المام التذريسي في قسم التربية الفنية بطرائق التدريس الحديثة وكيفية توظيفها في تدريس المادة الدراسية التي يقوم بتدريسها ضمن المرحلة الدراسية المقررة لها. 
جدول (v)

يبين كفاية تدريسي التربية الفنية ضمن مجال التقويم

\begin{tabular}{|c|c|c|c|c|c|c|}
\hline \multirow{2}{*}{ 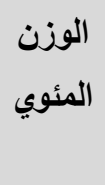 } & \multirow{2}{*}{ الحدة } & \multicolumn{3}{|c|}{ أمارسها بدرجة: } & \multirow[b]{2}{*}{ كفايات مجال التقويم } & \multirow[b]{2}{*}{$ت$} \\
\hline & & 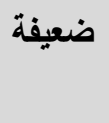 & 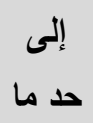 & كبيرة & & \\
\hline 0,69 & 2,09 & 6 & 7 & 8 & أراعي الاستمرارية في نقويم الطلبة & 1 \\
\hline 0,66 & 2,00 & 10 & 1 & 10 & أطبق لسليليب التقويم المنلبة لقلس مدى تحقيق الأهاف. & 2 \\
\hline 0,68 & 2,04 & 8 & 4 & 9 & أنوع في أسلايب التقويج بما ينالثم مع الأهداف التخليمية. & 3 \\
\hline 0,66 & 2,00 & 8 & 5 & 8 & استخدم اختبارات لتقويم المهارات المتتوعة. & 4 \\
\hline 0,69 & 2,09 & 5 & 9 & 7 & أراعي الفروق الفردية عند إجراء الاختبار . & 5 \\
\hline 0,69 & 2,09 & 5 & 7 & 9 & أراعي مفردات المنهاج عند التقويم. & 6 \\
\hline 0,76 & 2,28 & 5 & 5 & 11 & موقف تعليمي. النقويم الختامي الذي يجري في نهاية كل & 7 \\
\hline
\end{tabular}

من خلال النظر إلى نتائج الجدول(V) يتبين للباحثاين أن درجات الحدة

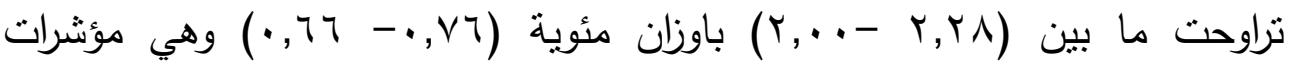
متوسطة في قيمها تدل على أن التدريسي في قسم التربية الفنية يفتقر إلى الإلمام بطرائق القياس والتقويم التي تعد من المهام الأساسية في عملية التريس. 
إن الكفايات التعليمية الأساسية ضرورية لتدريسي التربية الفنية والتي يجب إن تستخدم كمعيار للمدرس الكفء التي تم تحديدها ضمن مجالات الأداة، لذلك استتنج

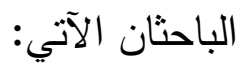

ا-ظهور مؤشرات إيجابية تدل على وعي التدريسي بالأهداف التعليمية للمادة

الدراسية التي يقوم بتدريسها ضمن المرحلة الدراسية المقررة لها. ץ-ظهور مؤشرات جيدة تدل على وعي التدريسي بأهمية التخطيط للمادة الدراسية التي يقوم بتدريسها ضمن المرحلة الدراسية المقررة لها. ب-ظهور مؤشرات جيدة تدل على قدرة التدريسي بتتفيذ متطلبات المادة الدراسية التي يقوم بتدريسها ضمن المرحلة الدراسية المقررة لها. ع-ظهور مؤشرات جيدة تدل على إلمام التذريسي في قسم التربية الفنية بطرائق التدريس الحديثة وكيفية توظيفها في تدريس المادة الدراسية التي يقوم بتدريسها ضمن المرحلة الدراسية المقررة لها. ه-ظهور مؤشرات متوسطة في قيمها تدل على أن التربيسي في قسم التربية الفنية يفتقر إلى الإلمام بطرائق القياس والتقويم التي تعد من المهام الأساسية في عملية التدريس. 
1- تكثيف الدورات التدريبية من قبل الاختصاصبين التربوبين كنماذج تطبيقية لتطوير التدريسي.

ץ- حث التربوبين على النمو الأكاديمي والمهني ذاتيَّا لأهميته وارتباطه بالنمو المهني لديهم. 


\section{الهوامش}

1- ترجم مصطلح Compétence بألفاظ مختلفة ك (ملكة، قدرة، كفاية) ونرجع مصطلح الكفاية

كونه يخدم موضوع البحث.

\section{المصادر والمراجع}

1- جامع، حسن وحصة الثاهين، الكفايات التدريسية اللازمة لمعلمي المرحلة الإبكائية في ولة الكويث،

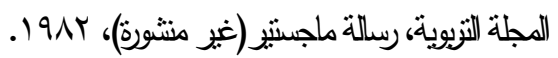

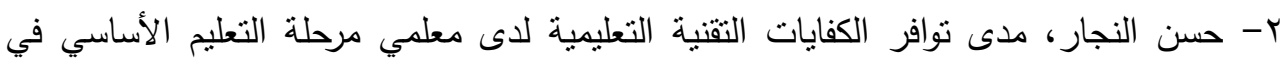

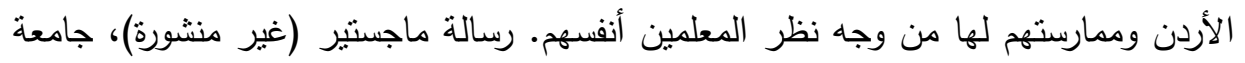

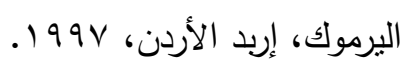

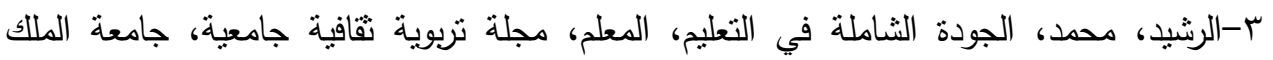

$$
\text { سعود، } 990 \text { ام. }
$$

ع-الفتلاوي، سهيلة، محسن كاظم، كفايات التدريس، المفهوم، التنريب، الأده، دار الثروق للنشر

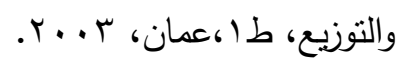

0- المطلق، فرح سليمان، كفايات الدرس الناجح وصفاته من وجهة نظر الموجين الاختصاصيين والطلبة- دراسة ميدانية في المرحلة الثانوية في مدينة دمشق، مجلة اتحاد الجامعات العربية للتربية

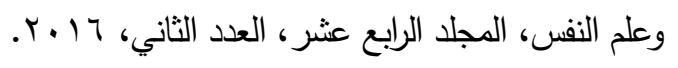

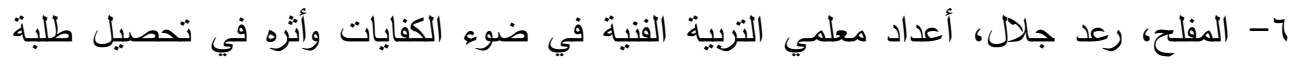

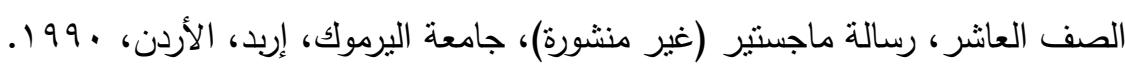

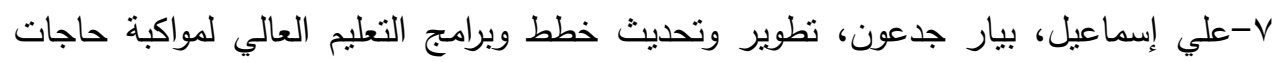

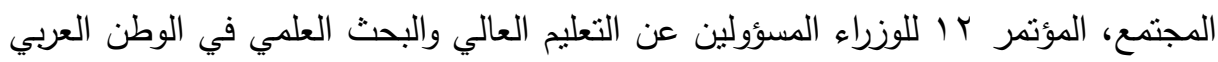

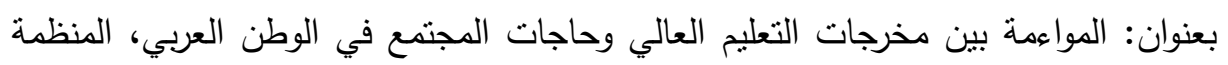

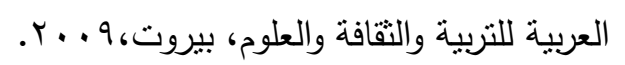

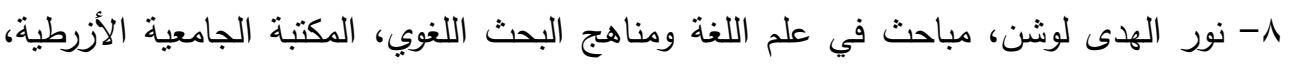

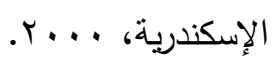

9-هادي نهر، أحمد الخطيب، إدارة الاتصال والتواصل، النظرية-العمليات-الوسائط، الكفايات،

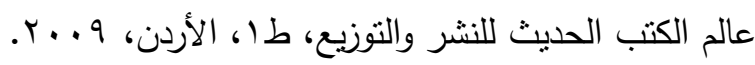


• 1-هادي نهر، الكفايات التواصلية والاتصالية، دراسات في اللغة والإعلام، طا، دار

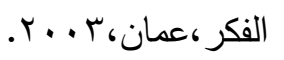

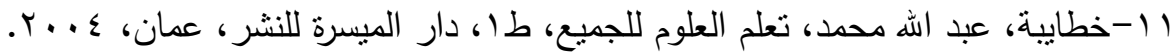

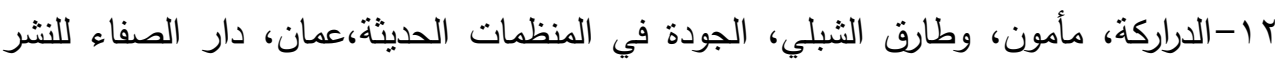

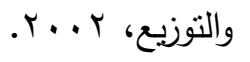

rا-عمار بن عبشي، إمكانية تطبيق مبادئ إدارة الجودة الثشاملة في الجامعات الجزائرية دراسة

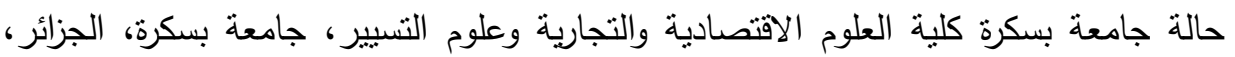

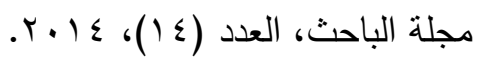

ع ا-محسن علي عطية، الجودة الثناملة والجديد في التدريس، طا، دار صفاء للنشر والتوزيع،

$$
\text { عمان، } 9 \text {. . T. }
$$

10-فاطمة عيسى أبو عبده، درجة تطبيق معايير إدارة الجودة الثاملة في مدارس محافظة نابلس

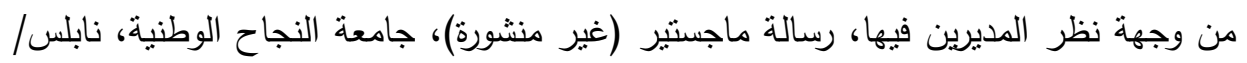

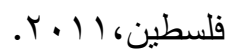

7 ا-عليمات، ناصر، إدارة الجودة الثناملة في المؤسسات التربوية التطبيق ومقترحات التطوير،

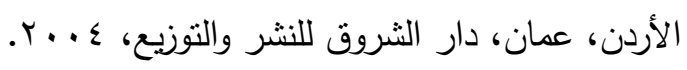

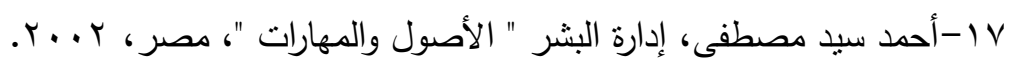

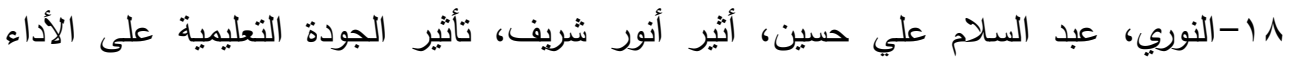

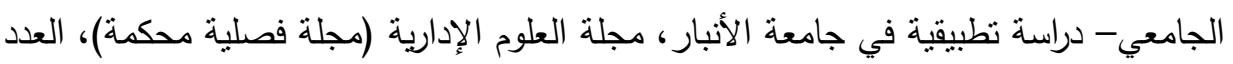

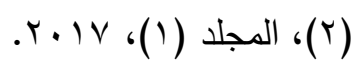

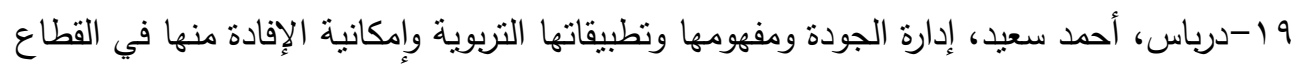

$$
\text { التعليمي السعودي، رسالة الخليج العربي، الرياض، العدد ـ } 99 \text { 1، ـ0. }
$$

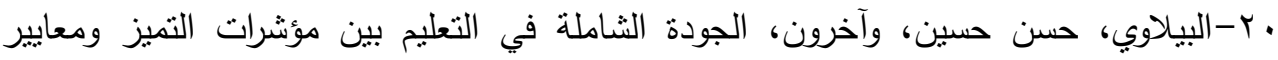

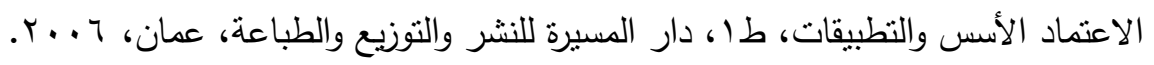

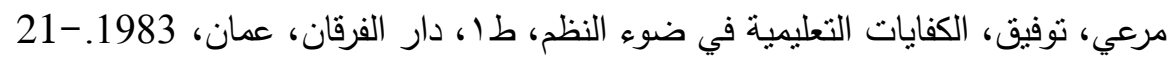

22- Cohen.E,"Dictionnaire de gestion", Editions La découverte, Paris, 2000.

23-Fernandez. A," Les nouveeaux tableaux de bord des décideurs", Editions d'Organisation, Paris, 2000. 


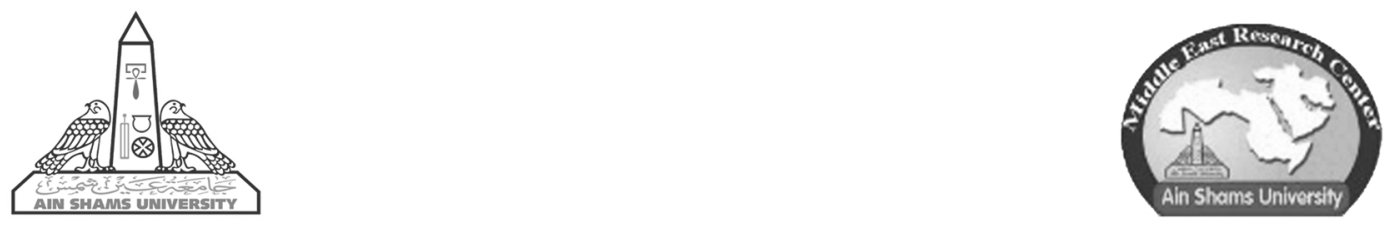

\section{Middle East Research Journal}

\section{Refereed Scientific Journal ( Accredited) Monthly Issued by Middle East Research Center}

Forty-eighth year - Founded in 1974

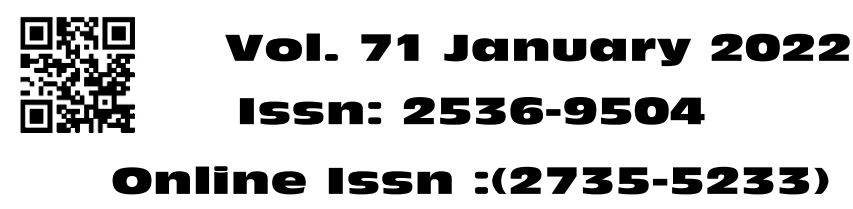

